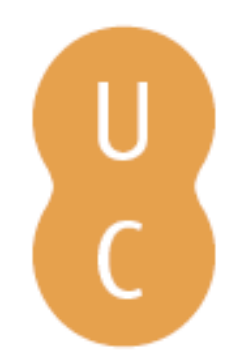

\title{
nombalina
}

\section{Precipitation and the hydrology of the Mondego catchment: a scale-invariant study}

Autor(es): $\quad$ Lima, Maria Isabel Pedroso de; Lima, João L. M. Pedroso de

Publicado por: Imprensa da Universidade de Coimbra

URL

persistente:

URI:http://hdl.handle.net/10316.2/32642

DOI:

DOI:http://dx.doi.org/10.14195/978-989-26-0336-0_2

Accessed : $\quad$ 26-Apr-2023 12:11:55

A navegação consulta e descarregamento dos títulos inseridos nas Bibliotecas Digitais UC Digitalis, UC Pombalina e UC Impactum, pressupõem a aceitação plena e sem reservas dos Termos e Condições de Uso destas Bibliotecas Digitais, disponíveis em https://digitalis.uc.pt/pt-pt/termos.

Conforme exposto nos referidos Termos e Condições de Uso, o descarregamento de títulos de acesso restrito requer uma licença válida de autorização devendo o utilizador aceder ao(s) documento(s) a partir de um endereço de IP da instituição detentora da supramencionada licença.

Ao utilizador é apenas permitido o descarregamento para uso pessoal, pelo que o emprego do(s) título(s) descarregado(s) para outro fim, designadamente comercial, carece de autorização do respetivo autor ou editor da obra.

Na medida em que todas as obras da UC Digitalis se encontram protegidas pelo Código do Direito de Autor e Direitos Conexos e demais legislação aplicável, toda a cópia, parcial ou total, deste documento, nos casos em que é legalmente admitida, deverá conter ou fazer-se acompanhar por este aviso. 
MIGUEL ÂNGELO PARDAL JOÄO CARLOS MARQUES MANUEL AUGUSTO GRAÇA Scientific Editors

\section{Aquatic Ecology of the Mondego River Basin Global Importance of Local Experience}




\author{
MIGUEL ÂNGELO PARDAL \\ JOẢO CARLOS MARQUES \\ MANUEL AUGUSTO GRAÇA \\ Scientific Editors
}

\title{
Aquatic Ecology of the Mondego River Basin Global Importance of Local Experience
}




COORDENAÇÃO EDITORIAL
Imprensa da Universidade de Coimbra
CONCEPÇÃO GRAFICA
António Barros
INFOGRAFIA
António Resende
Estimulus [design] • Coimbra
EXECUÇÃO GRAFICA
GRAFIASA
ILUSTRAÇÃO DA CAPA
P. P. Cunha e ]. Dinis
ISBN
972-8704-04-6
DEPOSITO LEGAL
I75038/02

(C) JANEIRO 2002, IMPRENSA DA UnIVERSIDADE DE COIMBRA

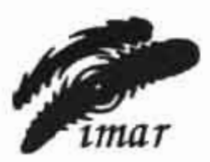

CPIMAR

imar

OBRA PUBLICADA COM O PATROCINIO DE:

IMAR - INSTITUTO DO MAR

IPIMAR - INSTITUTO DE INVESTIGAÇĀO DAS PESCAS E DO MAR 



\author{
Maria Isabel Pedroso de lima ' \\ JOÃo L. M. PEDROSO DE LIMA ${ }^{2}$
}

\title{
PRECIPITATION AND THE HYDROLOGY OF THE MONDEGO CATCHMENT: A SCALE - INVARIANT STUDY
}

\begin{abstract}
Precipitation in the Mondego drainage basin, in Portugal, is a highly variable input into the hydrological system of this region, strongly affecting water resources management Precipitation is a highly non-linear hydrological process that exhibits wide variability over a broad range of time and space scales. The strongly irregular fluctuations of precipitation. which in certain cases lead to catastrophic events, have strong socio-economic impacts, related to the occurrence of floods and droughts, reservoir management policies, etc.

Many approaches to the study of precipitation fail to grasp the extreme variability of this process. The invariance of properties across scales and the multifractality of precipitation may offer an alternative approach to quantify this variability. Thus, to increase our understanding of the precipitation variability in the Mondego basin, this work explores the invariance of properties manifested across scales and the fractal and multifractal behaviour observed in the temporal structure of precipitation, using daily precipitation data from two locations in this catchment: Coimbra and Penhas Douradas. The data cover a period of 54 years. The study is based on spectral analysis, box-counting analysis, and investigation into the scaling of probability distributions and statistical moments of the precipitation intensity. Results show the presence of scale-invariant and multifractal properties in the temporal structure of precipitation.
\end{abstract}

\section{Introduction}

Precipitation exhibits a high non-linear variability over a wide range of time and space scales. This variability involves a large dynamic range, which in certain cases leads to catastrophic events. Precipitation phenomena range from cells (associated with

19. IMAR - Instrtuto do Mar, Centro Interdisciplinar de Coimbra, Escola Supenor Agrária de Coimbra. Departamento Florestal. Instituto Politécnico de Coimbra, Bencanta. 3040.316 Coimbra, Portugal

क) IMAR - Instituto do Mar. Centro Interdisciplinar de Coimbra, Departamento de Engenharia Civil . Pólo 2 da Universidade de Coimbra, 3030-290 Coimbra. Portugal 
cumulus convection), to synoptic areas (frontal systems). Precipitation cells have an area of the order of $1-10 \mathrm{~km}^{2}$ and lifetimes of several minutes. Synoptic precipitation fields can cover areas of $10^{4} \mathrm{~km}^{2}$ and have a lifetime of one to several days.

Precipitation is the driving agent of many other processes. Its temporal and spatial variability are important issues in many studies and areas of research (e.g. hydrology. hydraulics, agronomy, soil pollution, water resources). However, information on the amount and distribution of precipitation in space and time is often restricted precisely because of this strong temporal and spatial variation, which many approaches to the study of precipitation fail to grasp.

The purpose of this work is to contribute to a better understanding of precipitation in the river Mondego drainage basin, in the Centre of Portugal (Figure 1). The strongly irregular fluctuations of river discharge, in both the Mondego River and its main first-order tributary streams, have led to different actions being taken with respect to the watercourses, aiming at diminishing the effect of hydrological extremes. In the past, until the end of the seventies, frequent flooding of the lower-lying lands near the estuary of the river (downstream of Coimbra, see Figure I) had strong socioeconomical impacts. These floods occurred nearly every year, with calamitous consequences. In the same region, fresh water was also often scarce due to the uneven distribution of precipitation during the year, and intrusion of saline water in the river and in the groundwater.

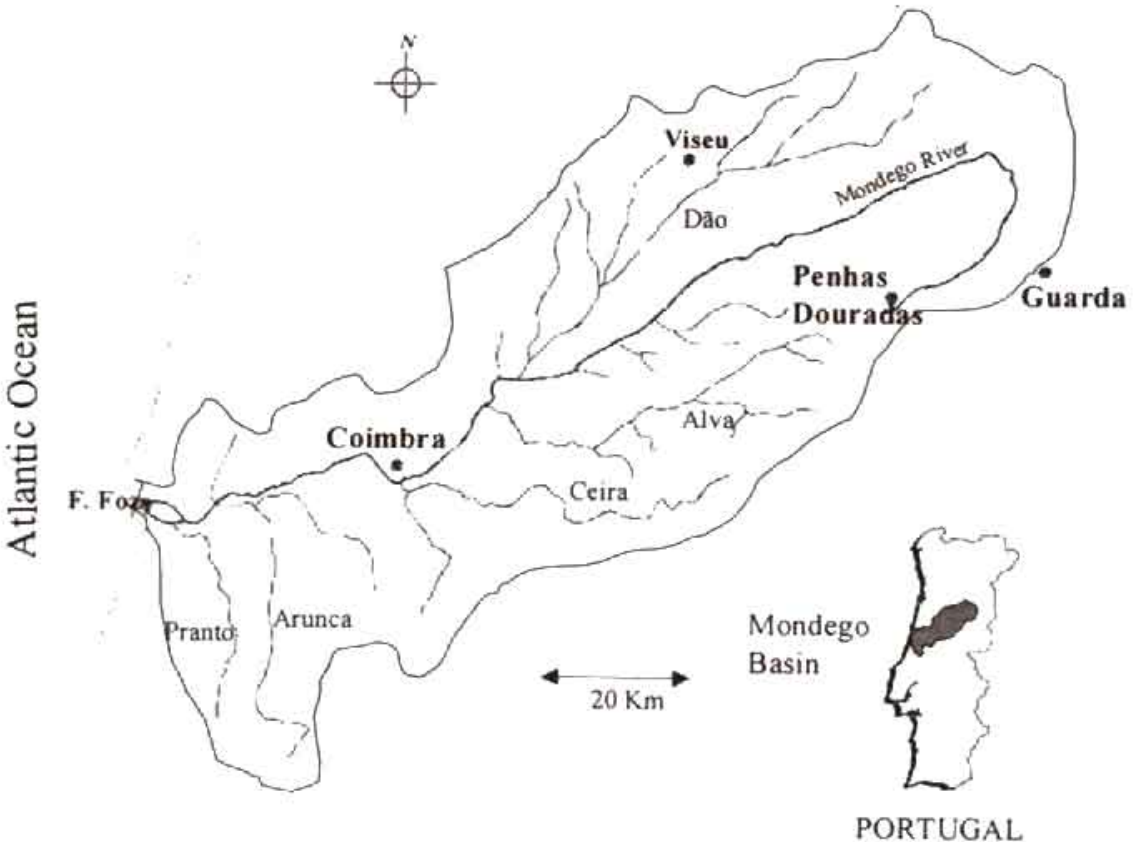

Figure 1. Map of Mainland Portugal localising the Mondego Basin, and an enlarged view of the catchment area locating the River Mondego and its main first-order tributaries, the main cities, and the two meteorological stations used in this study (Coimbra and Penhas Douradas). 
These and other problems led to the development of a multipurpose hydroagricultural project in the Mondego basin. The works carried out in the river and in the lower part of the drainage basin include flood protection works, and irrigation and drainage works. The management of its different components is very much dependent on the highly variable precipitation input into the hydrological system. Some difficulties arise from the lack of knowledge on the temporal and spatial distributions of precipitation in the catchment. For example, hydrological models usually have to conceptualise processes based on simple, often homogeneous, approximations of nature (e.g. precipitation is expressed as a mean over large areas, and as depths over periods of a day). Such generalised conceptualisations often lack sufficient temporal and spatial resolution to permit a detailed modelling of complex hydrological processes.

Recent events (December 2000/January 2001). with catastrophic consequences related to the occurrence of floods in the Lower Mondego region due to several ruptures of the protection dikes of the Mondego River, had a strong socio-economic impact and put pressure on decision makers to re-evaluate the entire project.

An important contribution towards increasing our understanding of the nonlinear variability in precipitation is being given by scale-invariant studies of this process. The invariance of properties being maintained across scales can be mathematically investigated using fractal and multifractal theories. These theories offer an alternative to ('conventional') approaches that study one scale independent of the other, Instead, they investigate the presence of certain features of a dynamic system that are independent of scale. The present study uses these theories to investigate the scale-invariant temporal structure of precipitation in the Mondego drainage basin. The work uses daily precipitation data from two locations in the drainage basin, Coimbra and Penhas Douradas, over a period of 54 years.

\section{General description of the Mondego River drainage basin and its hydrology}

The Mondego River is the longest watercourse whose entire course lies within Portugal. Its source is in the Serra da Estrela, in Central Portugal, at an altitude of $1,547 \mathrm{~m}$, and it flows into the Atlantic Ocean, near the city of Figueira da Foz, $234 \mathrm{~km}$ later (see Figure 1). The average slope of the Mondego riverbed is $0.637 \%$ (Lencastre and Franco 1984). The main first-order tributary streams entering the Mondego River are the Dão, on the right bank, and the Pranto. Arunca, Ceira and Alva, on the left bank

The Mondego drainage basin has an area of approximately $6,645 \mathrm{~km}^{2}$, being the second biggest river catchment area totally located in Portugal. Its shape is elongated, with its axis oriented approximately NE-SW, and is located approximately between $39^{\circ} 46^{\prime} \mathrm{N}$ and $40^{\circ} 48^{\prime} \mathrm{N}$, and $7^{\circ} 14^{\prime} \mathrm{W}$ and $8^{\circ} 52^{\prime} \mathrm{W}$. The highest altitude in the drainage basin is almost $2,000 \mathrm{~m}$ above sea level. The mean altitude is around $375 \mathrm{~m}$.

The climate of the Mondego basin is Mediterranean and strongly influenced by the proximity of the Atlantic Ocean. The Atlantic influence increases the relative humidity of the air and affects temperatures and precipitation. In the summer, low precipitation and high temperature and insolation can occur due to the presence and 
influence of the Azores high-pressure system. In the winter, many days have precipitation and mild temperature, strongly influenced by the passage of frontal surfaces and depressions moving from West to East, coming from the Atlantic Ocean.

The average annual temperature in the basin is approximately $13^{\circ} \mathrm{C}$. The warmest part of the basin is near the coast (in the Lower Mondego region), where the average annual temperature is around $16{ }^{\circ} \mathrm{C}$. The coldest regions are in the high lands of Estrela and Caramulo Mountains, where the average annual temperature is only $10^{\circ} \mathrm{C}$. Near the coast, the variation of temperature during the year is small because of the influence of the Atlantic Ocean. As the distance to the ocean increases, the temperature range increases. In the Mondego basin, the average temperature for the hottest months of July and August is $19^{\circ} \mathrm{C}$, and for the coldest months of December and January it is $6^{\circ} \mathrm{C}$.

The average annual insolation in the basin is around $2.400 \mathrm{~h}$ and the mean annual evapotranspiration is around $720 \mathrm{~mm}$.

The mean annual precipitation in the basin is approximately $1,130 \mathrm{~mm}$. The period from October to March is the humid semester, registering about $70 \%$ of the annual precipitation (for the two locations in the basin, see Figure 4(c)). The wettest month is December, with around $160 \mathrm{~mm}$ of precipitation. The driest months are July and August, with a monthly precipitation of around $15 \mathrm{~mm}$. In the dry season, months often register zero-precipitation.

Topography has a striking influence on both temperature and precipitation (Figure 2). There is a clear increase in precipitation and decrease in temperature with altitude, as one goes from the lower lands towards the hills.

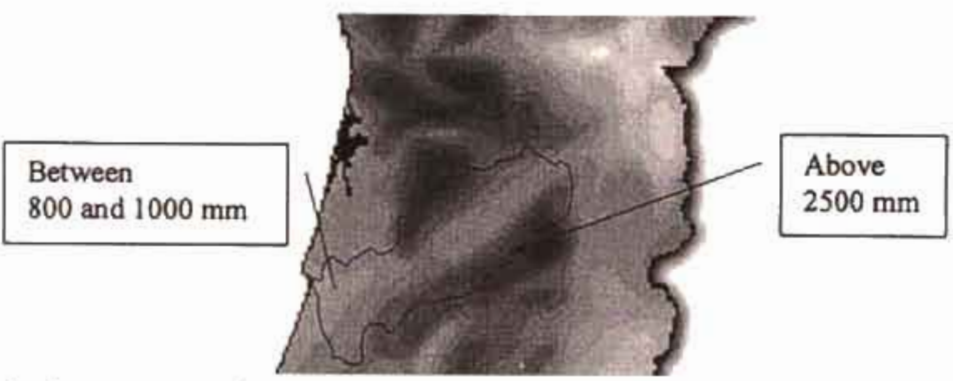

Figure 2. Spatial variation of mean annual precipitation in the Mondego River Basin. The highest values of precipitation (darker areas) are recorded in the mourtainous regions of Estrela and Caramulo and the lowest (lighter areas) in the Lower Mondego Region. near the Atlantic coast. (Adapted from DGA 1989)

It is possible to define three hydro-morphologic regions in the Mondego basin, based on different morphologic and climatic characteristics, hydrologic regimes and land use:

- Upper Mondego, corresponding to the mountainous region, where the river runs through valleys formed in the ice age. This region includes, among others, parts of the drainage basins of the Däo and Alva tributaries, and the upper section of the Mondego River. 
- Middle Mondego, which occupies the area lying between the outskirts of the Serra da Estrela mountains and the city of Coimbra. In this part of the Mondego catchment, the riverbed, which initially runs along a narrow valley, progressively broadens. This section of the river contains the outlets of the rivers Däo, Alva, and Ceira.

- Lower Mondego corresponds to the last section of the basin between Coimbra and the sea. In this area the river has a wide valley. The main tributaries of the Mondego River in this area are the rivers Arunca, Pranto and Foja.

The total resident population in the Mondego basin is around 680 thousand inhabitants (MA 2000). In this region the land is predominantly occupied by forest. In recent years the area occupied by forest has increased as the agricultural area diminished; forest accounted for $45 \%$ of ground cover in 1985 and $54 \%$ in 1990.

The Mondego River has a mean annual runoff of approximately $86 \mathrm{~m}^{3 / \mathrm{s}}(403 \mathrm{~mm}$ or $\left.27 \times 10^{9} \mathrm{~m}^{3}\right)$, at the outlet. The mean runoff of the driest month is around $0.015 \times 10^{9} \mathrm{~m}^{3}$ and of the wettest month is $0.530 \times 10^{9} \mathrm{~m}^{3}$ (MA 2000). The hydrological discharges of the Mondego River and its main first-order tributary streams are extremely irregular. In Coimbra, approximately $40 \mathrm{~km}$ from the estuary, the river flow has reached discharges as high as $3.000 \mathrm{~m}^{3} / \mathrm{s}$, in strong contrast with discharges of less than $1 \mathrm{~m}^{3} / \mathrm{s}$. occurring several days a year (natural situation before the human intervention). This has frequently led to flooding, and water supply problems, mainly for agricultural purposes. Flooding is still a problem in the Mondego basin, although several dams have been constructed, and these are able to control the great majority of flood situations in roughly $80 \%$ of the basin area. For approximately 20 consecutive years, the regulation and protection scheme managed to control the river discharges against floods. Recent flooding events are leading to a re-evaluation of the project and of its management and maintenance.

The most important hydraulic works in the Mondego basin are the dams at Aguieira. Fronhas, Raiva and the barrage at Coimbra, the Serra da Estrela hydroelectric system, and the irrigation and drainage systems of the Lower Mondego region. The diversity of water uses (e.g. for supplying populations, agriculture, industry, energy production) is extremely important for the economy of the region. In fact, the Mondego basin is the one registering the most extensive use of water resources in Portugal, namely for hydroelectric power (annual production of $360 \mathrm{GWh}$ ) and agriculture. The Lower Mondego hydro-agricultural scheme. which includes large irrigation and drainage systems, enhances the economic development of the region, where there are 15,000 ha of good agricultural land.

For mainland Portugal and, in particular, for the Mondego river drainage basin. Figure 3 shows a drought situation reconded in 1945 (Pimenta 1998), classified according to Palmer (1965). The Palmer Drought Severity Index is based on the supplyand-demand concept of the water balance equation, and is calculated using precipitation and temperature data, and the available water content of the soil. The values of the Palmer Index that are indicated in Figure 3 are average values for the year of 1945. Pimenta (1998) and Pimenta and Lima (1999) studied the occurrence of droughts in mainland Portugal, using monthly precipitation and air temperature time 
series from 70 stations of the Portuguese climatological network, for the period 1941 to 1992. Their study shows that, during this period, there were droughts affecting most of the territory, including the Mondego catchment area. Because of the uneven distribution of precipitation during a year, with the dry season coinciding with the warmest months, the Palmer Index yearly average indicates the occurrence of extremely dry periods within a twelve-month period. These are often linked to important water shortage problems, already mentioned above.

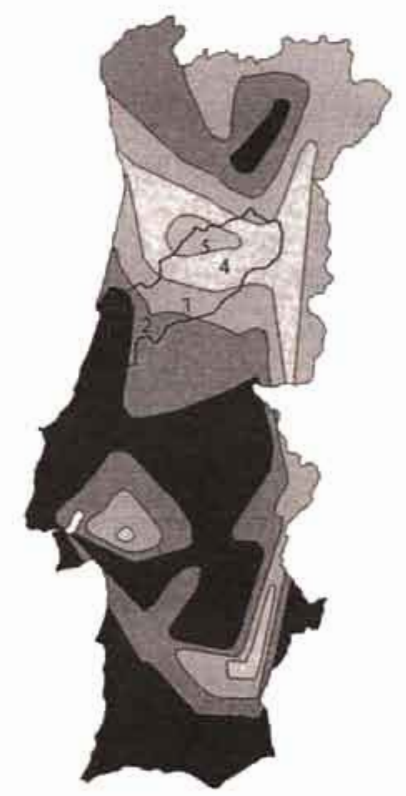

Figure 3. Impact of one of the most severe droughts (year of 1945) observed in Mainland Portugal and in the Mondego Basin, according to the Palmer dassification, where: 1 - Extremely dry, 2 -Very dry, 3 - Moderately dry, 4 - Slightly dry, and 5 - Incipient dry. (Adapted from Pimenta and Lima 1999)

\section{The precipitation data from Coimbra and Penhas Douradas}

The precipitation data used in the scale-invariant analysis (see below) were recorded at two locations in the river Mondego drainage basin, in Portugal: Coimbra/ Geofisico and Penhas Douradas (Serra da Estrela). The co-ordinates of these stations are approximately $40^{\circ} 12^{\circ} \mathrm{N}$ and $8^{\circ} 25^{\circ} \mathrm{W}$, for Coimbra, and $40^{\circ} 25^{\circ} \mathrm{N}$ and $7^{\circ} 33^{\circ} \mathrm{W}$, for Penhas Douradas. The altitude of the measuring sites is, respectively, $141 \mathrm{~m}$ and $1,380 \mathrm{~m}$ above mean sea level. Figure I shows the location of the measuring stations in the Mondego basin.

The precipitation measuring devices are of the 20-14-G type (according to the classification by Sevruk and Klemm. 1989); they have horizontal openings of $200 \mathrm{~cm}^{2}$ at $1.5 \mathrm{~m}$ height. The gauges were observed daily. The resolution of the measurements is $0.1 \mathrm{~mm}$ of precipitation. Trace precipitation of less than $0.1 \mathrm{~mm}$ is disregarded and such days are considered dry (zero-precipitation days). 

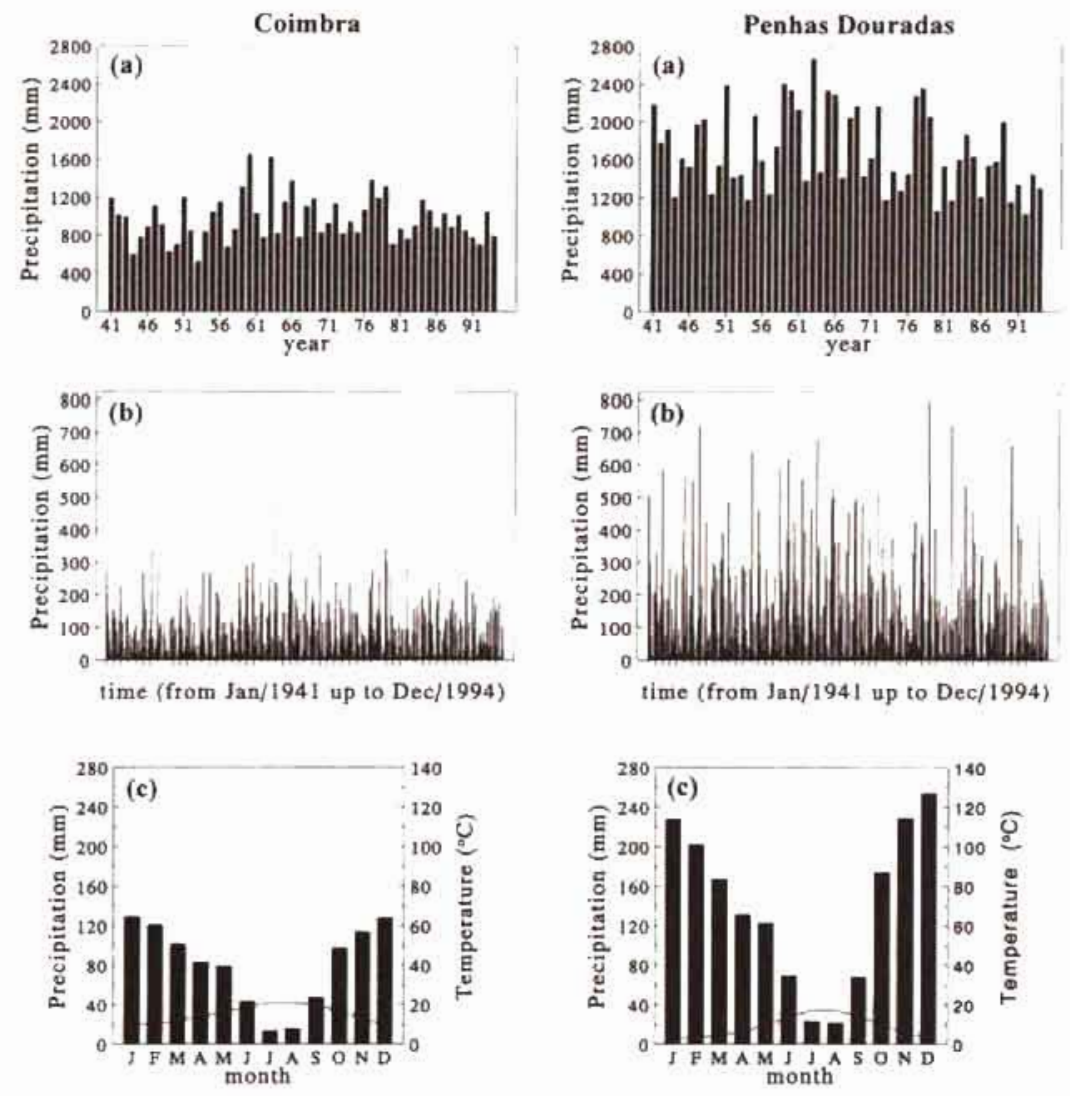

Figure 4. Preciprtation in Combra and Penhas Douradas, in the Mondego drainage basin, for the years 1941 1994: (a) annual precipitation; (b) monthly precipitation; and (c) average monthly precipitation. Figure (c) also shows the average monthly temperature, for the years 1947-1982.

The precipitation reconded in Coimbra and Penhas Douradas, for the years 1941 to 1994, is shown in Figure 4 and in Table 1. Figure 4(a) shows the annual precipitation. Figure 4(b) shows the monthly precipitation and Figure 4(c) shows the monthly average precipitation. The precipitation recorded in Coimbra and Penhas Douradas illustrates the spatial variability of precipitation in the Mondego basin, where the lowerlying land registers less precipitation, and the higher ground gives higher precipitation figures. Both locations exhibit a marked seasonal distribution of precipitation during the year. In Coimbra. of the 648 months that constitute this sample. 16 months had less than $1 \mathrm{~mm}$ of precipitation (roughly 2.5\%): among these, there are five months with less than $0.1 \mathrm{~mm}$. In Penhas Douradas, in the same period, there were 24 months with less than $1 \mathrm{~mm}$ of precipitation (roughly $3.7 \%$ of the sample); among these, there are seven months with less than $0.1 \mathrm{~mm}$ of precipitation.

Figure 4(c) also shows the average monthly temperature in Coimbra and Penhas Douradas, recorded from 1947 to 1982 . For this period, the mean annual temperature 
in Coimbra was $15.1^{\circ} \mathrm{C}$ and in Penhas Douradas it was $8.9^{\circ} \mathrm{C}$. On average, the coldest month was January, with $9.6^{\circ} \mathrm{C}$ in Coimbra and $2.8^{\circ} \mathrm{C}$ in Penhas Douradas. In Coimbra, the warmest months were July and August with $20.9^{\circ} \mathrm{C}$, and in Penhas Douradas July was the warmest, with $17.1^{\circ} \mathrm{C}$.

Table I. Summary of relevant precipitation data from Coimbra and Penhas Douradas, for the period 1941-1994.

\begin{tabular}{|c|c|c|}
\hline \multirow{2}{*}{$\begin{array}{l}\text { Type of precipitation data } \\
(1941-1994)\end{array}$} & \multicolumn{2}{|c|}{ Measuring stations } \\
\hline & Coimbra & Penhas Douradas \\
\hline $\begin{array}{l}\text { Mean annual precipitation } \\
\text { (coefficient of variation) }\end{array}$ & $\begin{array}{l}976.9 \mathrm{~mm} \\
(0.24)\end{array}$ & $\begin{array}{l}1692.2 \mathrm{~mm} \\
(0.25)\end{array}$ \\
\hline $\begin{array}{l}\text { Precipitation in wettest year } \\
\text { (wettest year) }\end{array}$ & $\begin{array}{l}1651.4 \mathrm{~mm} \\
(1960)\end{array}$ & $\begin{array}{l}2669.3 \mathrm{~mm} \\
(1963)\end{array}$ \\
\hline $\begin{array}{l}\text { Precipitation in driest year } \\
\text { (driest year) }\end{array}$ & $\begin{array}{l}524.2 \mathrm{~mm} \\
(1953)\end{array}$ & $\begin{array}{l}1023.9 \mathrm{~mm} \\
(1992)\end{array}$ \\
\hline $\begin{array}{l}\text { Average monthly precipitation } \\
\text { (coefficient of variation) }\end{array}$ & $\begin{array}{l}81.4 \mathrm{~mm} \\
(0.90)\end{array}$ & $\begin{array}{l}141.0 \mathrm{~mm} \\
(0.99)\end{array}$ \\
\hline $\begin{array}{l}\text { Precipitation in wettest month } \\
\text { (wettest month) }\end{array}$ & $\begin{array}{c}467.4 \mathrm{~mm} \\
\text { (November, 1963) }\end{array}$ & $\begin{array}{c}802.6 \mathrm{~mm} \\
\text { (December, 1978) }\end{array}$ \\
\hline $\begin{array}{l}\text { Precipitation in driest months } \\
\text { (total number of months) }\end{array}$ & $\begin{array}{l}0 \mathrm{~mm} * \\
(5 \mathrm{months})\end{array}$ & $\begin{array}{c}0 \mathrm{~mm} \\
\text { (7 months) }\end{array}$ \\
\hline $\begin{array}{l}\text { Average precipitation in wettest month } \\
\text { (average wettest month) }\end{array}$ & $\begin{array}{l}129.5 \mathrm{~mm} \\
\text { (January) }\end{array}$ & $\begin{array}{l}253.8 \mathrm{~mm} \\
\text { (December) }\end{array}$ \\
\hline $\begin{array}{l}\text { Average precipitation in driest month } \\
\text { (average driest month) }\end{array}$ & $\begin{array}{l}13.7 \mathrm{~mm} \\
\text { (July) }\end{array}$ & $\begin{array}{l}21.9 \mathrm{~mm} \\
\text { (August) }\end{array}$ \\
\hline
\end{tabular}

- Monthly precipitation below $0.1 \mathrm{~mm}$ is considered negligible.

20 Some aspects of fractal and multifractal theories

The invariance of properties manifested across scales can be investigated mathematically using fractal and multifractal theories. These theories apply to processes and systems that do not have a characteristic scale. Scale-invariance leads to a class of scaling rules (power laws) characterised by scaling exponents. This allows the relationship of variability between different scales to be quantified. Statistical properties of scale-invariant systems at different scales (i.e. on large and small scales) are related by a scale-changing operation that involves only scale ratios. 
Scaling theories are developed in a non-dimensional framework, because one is looking for features that are independent of the physical size of the study-object To nondimensionalise time measurements, one assumes that the duration of the longest period of interest is equal to $\mathrm{I}$. If this period has a duration $T$, then the magnitude of any time interval $\tau$ should be divided by $T$. Any time scale corresponding to $\tau$ can then be characterised by a scale ratio $\lambda$, with $I / \lambda=\tau / T$. To non-dimensionalise the precipitation intensity on a time scale of resolution $\lambda$, the intensity can be divided by the ensemble average intensity of the process. For precipitation this means the climatological average precipitation. Nevertheless, in practice, one generally uses the average intensity of the sample, which corresponds to the largest scale of interest $(\lambda=1)$. Let the (average) precipitation intensity for $\lambda=\mid$ be $\left\langle R_{\mathrm{t}}\right\rangle$, where the angular brackets $\left.<\right\rangle$ mean (ensemble) average. So if the precipitation intensity in a time interval $\lambda^{\prime}$ is $R_{\lambda}$, the corresponding non-dimensional intensity is $\varepsilon_{\mathrm{A}}=R_{\mathrm{A}} /\left\langle R_{\mathrm{l}}\right\rangle$, hence $\left\langle\varepsilon_{\mathrm{A}}\right\rangle=1$.

Using fractal theory (Mandelbrot 1977, 1982) one is dealing with simple scaling. Fractal behaviour is determined by one parameter. Fractal studies of the temporal structure of precipitation deal only with the oversimplified binary question of occurrence and non-occurrence of the process. The binary question (i.e. the definition of rainfall occurrence) is generally associated with a precipitation-intensity threshold. The geometric structure that is the 'support' of the precipitation process can be regarded as a fractal object embedded in the I-dimensional space of time and is defined as the set of precipitation periods observed in a particular location. Its fractal dimension, $D$, is between 0 and I. Very roughly, the fractal dimension of a set tells how densely the set occupies the metric space in which it lies. More generally. it tells how frequent a phenomenon is. The fractal dimension of a set can be determined with the box-counting method (e.g. Feder 1988. Hastings and Sugihara 1993).

The need to generalise the scaling properties of physical processes has led to the development of multifractal theory (Hentschel and Procaccia 1983. Grassberger 1983. Schertzer and Lovejoy 1983), dealing not with simple scaling but with multiscaling. It can handle the different intensity levels of processes. Multifractal behaviour is determined not by one, but by an infinity of scaling exponents.

One way to investigate the multifractal temporal structure of the precipitation process is by studying the (multiple) scaling of the probability distributions of the precipitation intensity (e.g. Schertzer and Lovejoy, 1987). The precipitation intensity threshold level is evaluated with the order of singularity $\gamma$ of the intensities $\varepsilon-\lambda^{\top}$ (e.g. Frisch and Parisi 1985. Halsey et al. 1986. Schertzer and Lovejoy 1987). The scaling of the probability distributions is given by the exponent function $c(\gamma)$ :

$$
\operatorname{Pr}\left(\varepsilon \geq \lambda \lambda^{y}\right) \approx \lambda \text { - } 2 x
$$

In literature, the function $c(\gamma)$ is called the codimension function. Eq. (I) holds for proportionality constants varying slowly with $\lambda$ and depending weakly on $\gamma$ (e.g. Schertzer and Lovejoy 1989, Lovejoy and Schertzer 1991). This statistical characterisation of multifractals arises directly from multiplicative cascade processes (see e.g. Schertzer and Lovejoy 1987). The scaling (power-law) behaviour can be tested with log-log plots of the probability of exceeding different levels of the precipitation 
intensity $\varepsilon$. observed on scales of differing levels of resolution $\lambda$, against the scale ratio $\lambda$ (e.g. Lavallée et al. 1991).

Another (equivalent) way to investigate the multifractal temporal structure of precipitation is with the statistical moments of the precipitation intensity (Schertzer and Lovejoy 1987). The scaling of the moments of precipitation intensity is described by the exponent function $K(q)$. The notion of moment can be generalised to any real value $q$. The moments' scaling function $K(q)$ satisfies:

$$
\left\langle\varepsilon, \varepsilon^{a}\right\rangle \approx \lambda<\mid
$$

Where $\left\langle\varepsilon^{4}\right\rangle$ is the (ensemble) average $q^{\text {st }}$ moment of the precipitation on a scale specified by $\lambda$. The scaling of the moments can be tested with log-log plots of the average $q^{\text {at }}$ moment of precipitation intensity $\varepsilon_{1}$, observed on scales of different levels of resolution $\lambda$, against the scale ratio $\lambda$. The two multifractal scaling exponent functions $c(\gamma)$ and $K(q)$ are (theoretically) non-linear increasing functions (concave functions).

One can also use standand spectral methods and analysis to test for scaleinvariance. The most familiar consequence of scaling is the power-law behaviour that is expected in the energy (power) spectra of scaling processes (e.g. Mandelbrot 1982, Schertzer and Lovejoy 1987, Ladoy et al. 1991. Lovejoy and Schertzer 1995):

$$
E(\omega) \approx \omega^{-\beta}
$$

where $\omega$ is the wave-number, $E(\omega)$ is the energy, and $\beta$ is the spectral exponent. For temporal processes, the wave number can be approximated by $\omega \sim 1 / \tau$, with $\tau$ being the magnitude of any time interval. Thus, in this application, $\omega$ is a frequency. The powerlaw behaviour of the spectra is expected to occur over a range of wave numbers and might not be observed for small samples.

\section{Scaling and multifractal analysis of daily precipitation data}

This Section deals with the analysis of the daily precipitation, over a penod of 54 years, from Coimbra and Penhas Douradas, recorded from 1941 to 1994. In the different analyses, given below, the statistics are accumulated for the 54 years covered by the data.

The energy spectra of the daily precipitation at these two locations are plotted in Figure 5. The spectra have been smoothed for high frequencies. The spectral peaks at $\omega \approx 0.0027$ day' correspond to the annual cycle frequency. The spectra exhibit power. law behaviour that extends from I day up to at least one month. The spectral exponent $B$ ( $E q .3$ ) is estimated as 0.28 , for the data from Coimbra, and 0.31 , for the data from Penhas Douradas. Parameters $B$ were estimated from the absolute values of the slopes of the regression lines fitted to the right-hand side scaling regions of the spectra, plotted in log-log axis. For scales larger than one to two months, up to roughly one decade, one can distinguish a rather flat section in the spectra. The scaling regime associated with the range of scales characterised by such a spectral plateau is expected 
to govern inter- and intra-seasonal variability (Fraedrich and Lamder 1993). This plateau is followed by another section (i.e., for even larger scales), indicating large-scale climatic variability, For other locations, e.g. Ladoy et al. (1991). Fraedrich and Larnder (1993). Tessier et al. (1996) and Svensson et al. (1996) have reported similar results.

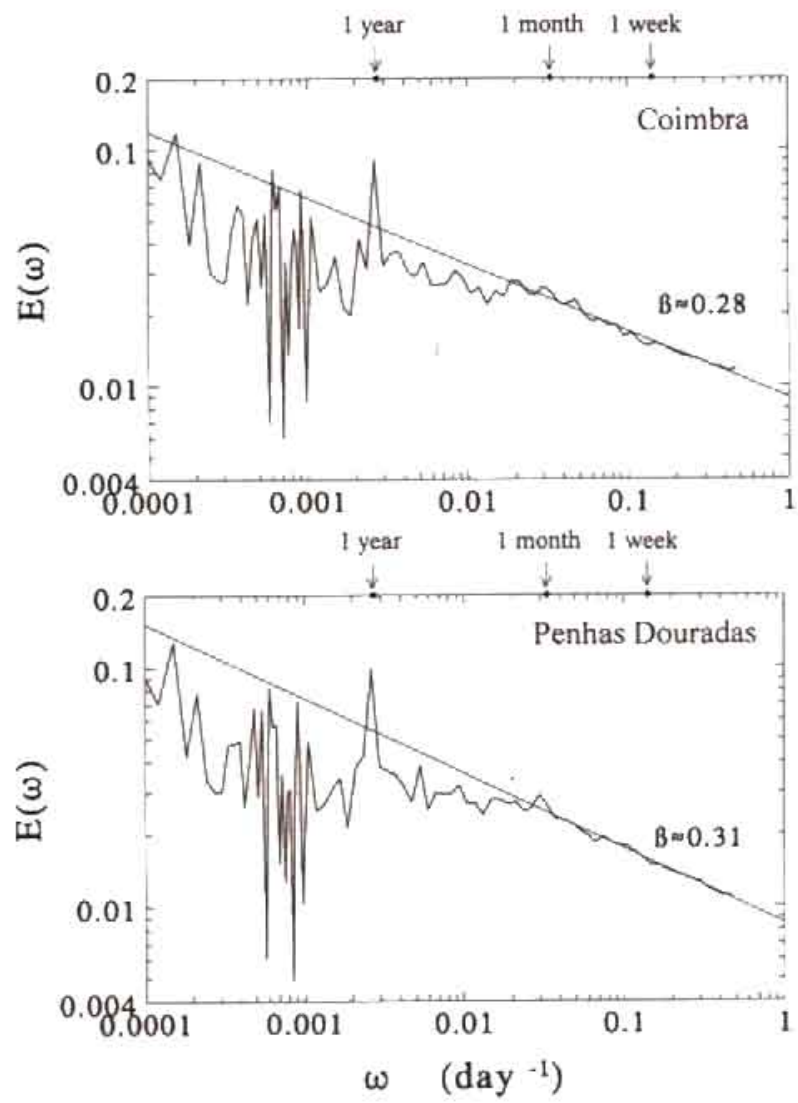

Figure 5. Energy spectra obtained for dally pnecipitation from Coimbra and Penhas Douradas, from 1941 to 1994.

The box-counting method can be also used to test the scale-invariant temporal structure of precipitation. The application of the box-countung method to precipitation, shown below, is based on a zero-precipitation threshold definition of precipitation occurrences. Figure 6 shows the box-counting plot obtained for the daily precipitation, for time scales from I day up to 8.5 months. A fractal dimension, 0.64 , characterises precipitation occurrences in Combra, on the range of scales from I day up to about 13 days. A similar fractal dimension, 0.65 , characterises precipitation occurrences in Penhas Douradas, on the range of scales from I day up to about 14 days. The fractal dimensions are estimated from the absolute value of the slopes of the regression (heavy) lines fitted to the left-hand side sections of the plots in Figure 6. Analysis of larger time scales is affected by 'saturation', which is a practical problem encountered when applying the box- 
counting method to precipitation occurrences. The regression (broken) lines fitted to the right-hand side sections of the plots in Figure 6 have (trivially) slope -1 .

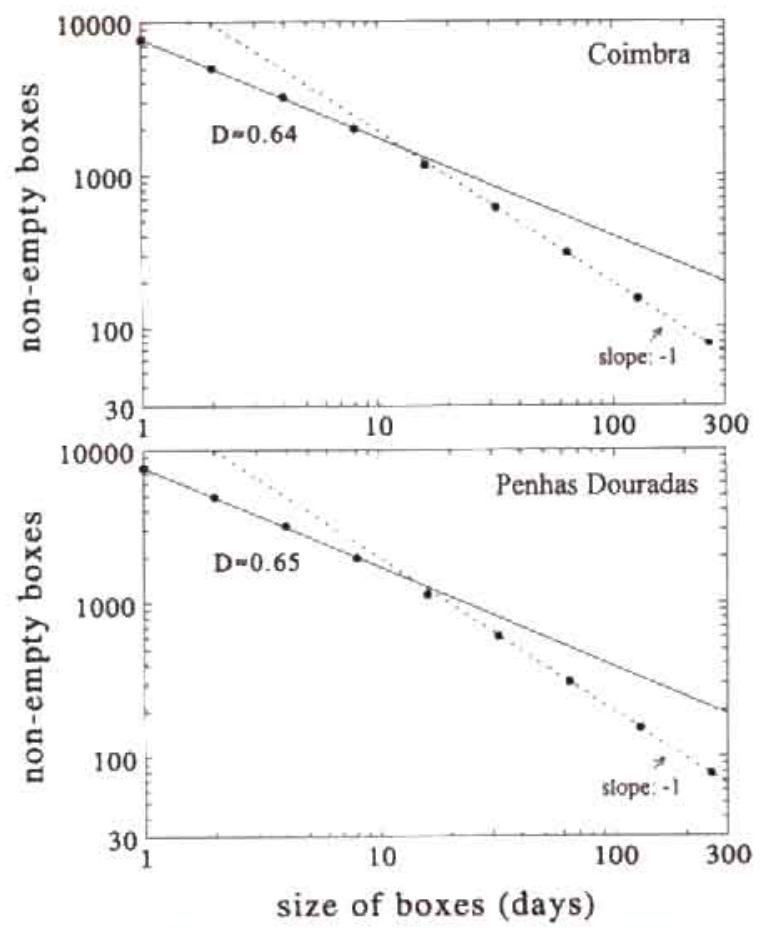

Figure 6. Box-counting plot obtained for daily precipitation from Coimbra and Penhas Douradas, for the period 1941 to 1994. The plot displays time scales from I day up to 8.5 months.

Figure 7 shows. for the data from Coimbra and Penhas Douradas, the log-log plot of the probability of exceeding precipitation intensity levels of singularity $\gamma$, observed on time scales from I day $(\lambda=256)$ up to 8.5 months $(\lambda=1)$, against the scale ratio $\lambda$. The orders of singularity $\gamma$ of the precipitation intensity plotted in Figure 7 are indicated in the legends. The scaling behaviour observed in Figure 7 is maintained from one day up to more than one month. The scaling range observed for Penhas Douradas seems to be larger than for the data from Coimbra. The probability plots in Figure 7 show regression lines fitted to the data that clearly indicate the presence of scale invariance in the temporal structure of precipitation.

Also relative to the data from Coimbra and Penhas Douradas, Figure 8 shows the $\log -\log$ plot of the average $q^{\text {* }}$ moments of precipitation intensity \& on time scales from I day $(\lambda=256)$ up to 8.5 months $(\lambda=1)$, against the scale ratio $\lambda$. Figure 8 (a) shows moments larger than I and Figure $8(b)$ moments smaller than I. The moments $q$ plotted in Figure 8 are indicated in the legend. For moments larger than I, the scaling range seems to extend from one day up to about one month, for the data from Coimbra, and up to about 2 months, for the data from Penhas Douradas. One expects that the scaling behaviour for some small moments, which highlight the small intensities of the data. would be affected by an incorrect description of the precipitation process by the data, 

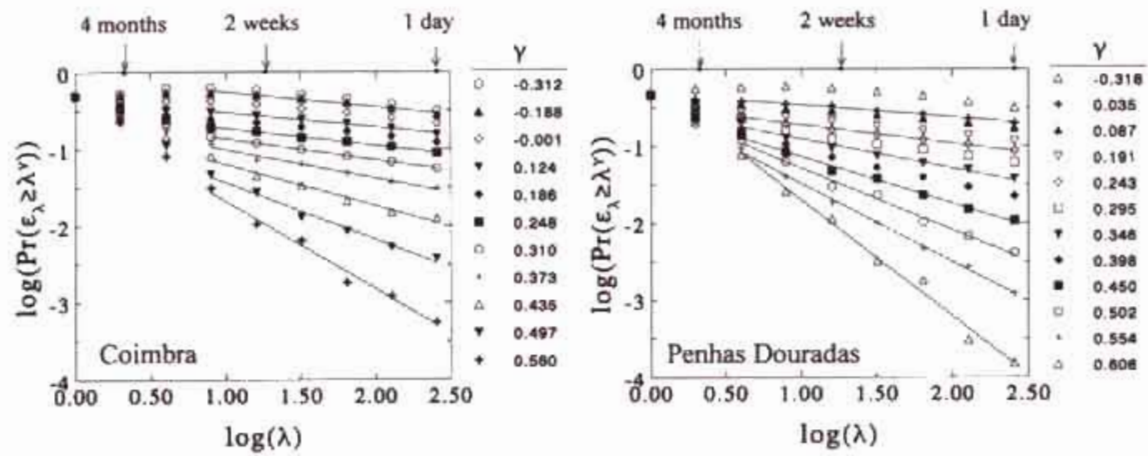

Figure 7. Log-log plot of the probability of exceeding precipitation intensity levels of singularity $\gamma$, observed on scales from I day $(\lambda=256)$ up to 8.5 months $(\lambda=1)$, against the scale ratio $\lambda$. The legend indicates the order of singularity $\gamma$ of the precipitation intensity $\varepsilon$. The plots are for the data from Coimbra and Penhas Douradas.

over this range of the precipitation dynamics. This could result from the inability of the measuring devices to record precipitation intensities smaller than a characteristic value.

The scaling functions $c(\gamma)$ and $K(q)$, in Eqs. (1) and (2) respectively, which would describe the statistics of precipitation in Coimbra and Penhas Douradas are obtained from the regression lines fitted to the probability plots in Figure 7 and moments' plots in Figure 8 , over the relevant range of orders of singularity $\gamma$, and moments $q$ of precipitation intensity.
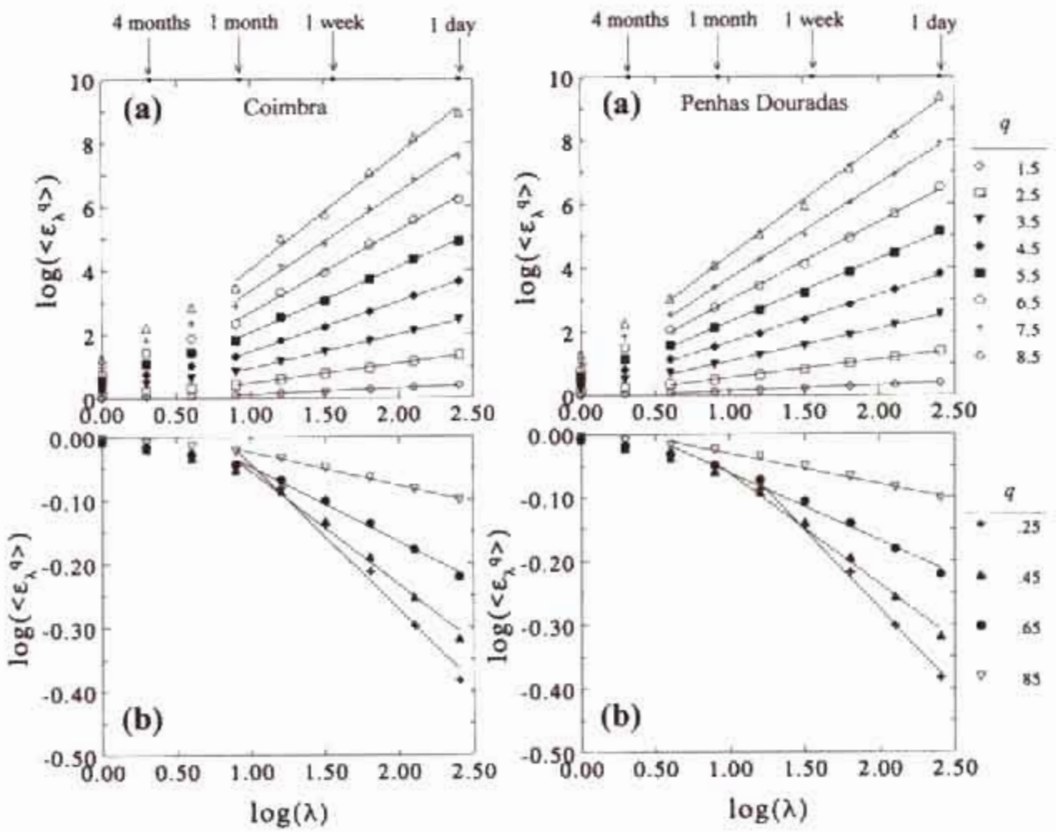

Figure 8. $\log$ - $\log$ plot of the average $q^{*}$ moments of the precipitation intensity $\varepsilon$ on scales between I day $(\lambda=256)$ and 8.5 months $(\lambda=1)$, against the scale ratio $\lambda \cdot$ (a) for moments larger than 1 ; and (b) for moments smaller than I. The plots are for the data from Coimbra and Penhas Douradas. 


\section{Concluding remarks}

This study shows the presence of scale-invariant and multifractal properties in the temporal structure of precipitation in the Mondego drainage basin. The study used daily precipitation from Coimbra and Penhas Douradas. Scale-invariant and multifractal properties are maintained from one day up to roughly one month. Results obtained for the data sets investigated are consistent with results reported by other researchers, for different precipitation data sets. One can refer to e.g. Ladoy et al. (1991). Hubert and Carbonnel (1991), Hubert (1992), Tessier et al. (1992), Ladoy et al. (1993), Tessier et al. (1993), Hubert et al. (1993). Lima et al. (1993), Olsson and Niemczynowicz (1994), Hubert (1995), Lima and Bogardi (1995). Harris et al. (1996). Svensson et al. (1996), Bendjoudi et al. (1997), Lima (1998, 1999) and Lima and Grasman (1999).

The scale-invariant and multifractal approach to the study of precipitation in the Mondego basin has still not been fully explored. There is still insufficient knowledge about the dependency of the multifractal behaviour of precipitation on climatological and geographical factors (i.e. on precipitation-generating mechanisms). Thus, more research is needed involving the study of precipitation from other locations. Further research should include the analysis of precipitation data from more locations in the Mondego catchment, and also the analysis of higher resolution precipitation time series (e.g. hours, minutes). This will allow us to characterise the precipitation process better. It will also allow us to fully explore the invariance of precipitation properties across scales. Some studies have already shown that this scale invariance is observed down to scales of the order of minutes (e.g. Lima 1998). Such properties permit us to use the statistics of precipitation derived, for example, from daily data to infer the statistics of precipitation at smaller time scales. The expectation is that the multifractal theory and its application in models (e.g. Schertzer and Lovejoy 1987) may be tools that help produce high-resolution synthetic precipitation data that can be used in many hydrological applications and studies (e.g. rainfall-runoff transformation, soil erosion, spread of pollutants, urban drainage). For the Mondego basin, this could greatly assist in water resources studies and management.

\section{Acknowledgements}

The authors are grateful to Dr. M. F. Espirito Santo Coelho, of the Portuguese Institute of Meteorology (IM), who kindly provided the precipitation data used in this work, within the framework of a joint research project PRAXIS/P/ECM/I2018/1998. This project is funded by the Portuguese Foundation for Science and Technology (FCT).

\section{References}

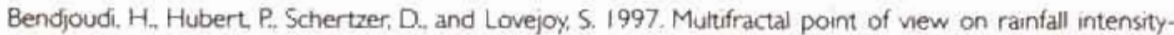
duration-frequency curves. C. R. Acad, Sci. Pans, Série II, Fasc A. 325(5): 323-326.

DGA - Direç̧ão Geral do Ambiente, 1989. Atlas do Ambiente Lisboa, Portugal.

Feder, 1. 1988. Fractals. Plenum Press, New York. 
Fraedrich, K, and Lamder, C. 1993. Scaling regimes of composite rainfall time series. Tellus 45A(4): 289-298. Frisch, U. and Parisi, G. 1985. Fully developed turbulence and intermittency. In Turbulence and predicability in geophysical fluid dynamics and climate dynamics. Edited by Ghil, M. R. Benzi, and G. Parisi Proc. of International School of Physics "Enrico Fermi", Course LXXXVIII, Italian Physical Society. North-Holland, Ansterdam

Grassberger. P. 1983. Generalized dimensions of strange attractors. Physics Reviews Letters 97A(6): 27-230.

Halsey, T. C., Jensen, M. H. Kadanoff, L P. Procaccia. I., and Shraiman, B. I. 1986. Fractal measures and their singularities: the characterization of strange sets. Physics Reviews Letters 33A(2): $1|4|-1151$.

Harris, D. Menabde, M., Seed, A., and Austin, G. 1996. Multifractal characterization of rain fields with a strong orographic influence. 1. Geophys Res. 101 (D21): 26405.26414.

Hastungs, H.M., and Sughara, G. 1993. Fractals a user's guide for the natural sciences. Oxford University Press, Oxford, U.K

Hentschel, H. G. E. and Procaccia, 1. 1983 The infinte rumber of generalized dimensions of fractals and strange attractors. Physica 8D: 435-444.

Hubert, P. 1992 Analyse multifractale de champs temporels d'intensité des précipitations. Rencontres hydrologiques Franco-Roumaines, UNESCO, Paris, 3-6 September, 1991, SC/92 WS/48, pp. 379.386.

Hubert. P. 1995 Fractals et multifractals appliqués à l'étude de la vanabilité temporelle des précipitations". In Space and time scale variability and interdependencies in hydrological processes. Edited by R A. Feddes. Cambridge University Press. U.K. pp. 175-181.

Hubert, P. and Cartonnel, J.-P. 1991. Fractal characterization of intertropical precipitations variability and anisotropy. In Non-linear variability in Geophysics: scaling and fractals. Edited by D. Schertzer and S. Lovejoy. Kluwer Academic Publishers, The Netheriands, pp. 209-213.

Hubert. P., Tessier, Y, Lovejoy. S. Schertzer, D. Schmitt. F. Ladoy, P. Cartoonnel, f. P. Violette, S, and Desurosne. 1.. 1993. Multifractals and extreme rainfall events. Geophys, Res. Lett. 20(10): 931 -934

Ladoy, P. Lovejoy, S., and Schertzer, D. 1991. Extreme variability of climatological data: scaling and intermittency. In Non-linear variability in Geophysics: scaling and fractals. Edited by D. Schertzer, and S. Lovejoy. Kluwer Academic Publishers, The Netherlands, pp. 241.250.

Ladoy. P. Schmitt. F. Schertzer. D. and Lovejoy, S. 1993. Vanabilité temponelle multifractale des observations pluviométriques à Nimes. C. R Acad. Sci. Paris, Séne \| 317:775-782

Lavallée, D., Schertzer, D., and Lovejoy, S. 1991. On the determination of the codimension function. In Nonlinear variability in Geophysics: scaling and fractals. Edited by D. Schertzer, and S. Lovejoy. Kluwer Academic Publishers, The Netherlands. pp. 99-110.

Lencastre, A. and Franco. F. M. 1984. Liçōes de Hidrologia. Universidade Nova de Lisboa, Faculdade de Ciências e Tecnologra. Lisboa. Portugal.

Lima, M. I. P. de. Torfs, P. J. J. F, and Bogardi, f. . 1993. Multifractal analysis of rainfall time senes. International Conference Nonlinear Variability in Geophysics 3. Scaling and multifractal processes (Abstract volume), September 10-17, 1993, Cargese, France

Lima. M. I, P. de, and Bogardi, J. J. 1995. Multifractals in hydrological studies the analysis of rainfall time series Proc of the UNESCO International Conference Statistical and Bayesian Methods in Hydralogical Sciences. September II- 13, 1995. UNESCO. Paris. France, Vol. II

Lima, M. I. P. de 1998. Muttifractals and the temporal structure of rainfall. Ph.D. thesis, Wageningen Agricultural University, The Netheriands.

Lima, M. I, P de 1999. A fractal and multifractal study of hourly precipitation time-senes from the Netherlands. In Hydrologic Modeling, Edited by V P. Singh, II W. Seo and J. H. Sonu Water Resources Publications, LLC. USA. PP. 15-28.

Lima, M. L. P. de, and Grasman, 1. 1999. Multifractal analysis of 15 -min and dally rainfall from a semi-arid region in Portugal. J. Hydrol. 220, 1-11.

Lovejoy, S. and Schertzer, D. 1991 . Multuractal analysis techniques and the rain and cloud fields from 10-3 to $106 \mathrm{~m}$. In Non-linear variability in Geophysics scaling and fractals. Edited by D. Schertzer and S. Lovejoy. Kluwer Academic Publishers, The Netherlands, pp. I I | - 144

Lovejoy, S. and Schertzer. D. 1995. Multufractals and ran. In New Uncertanty Concepts in Hydrology and Water Resources. Edited by Z.W. Kunzewicz. UNESCO series in Water Sciences, Cambndge University Press, New York, pp. 62.103.

MA - Ministério do Ambiente, 2000. Plano de bacia hidrográfica do Rio Mondego. I" Fase - Análise e Diagnóstico da Situação de Referencia; Sintese da Análise e Diagnóstico da Situaçầo Actual, Volume I - 
Sumáno Executivo. Ministério do Ambiente, Instituto da Água, Direç̧ão Regional do Ambiente do Centro.

Mandelbrot B. 1977. Fractals: form, chance and dimension. Freeman, San Francisco, 365 p.

Mandelbrot, B. 1982. The fractal geometry of nature. Freeman, San Francisco, $460 p$.

Olsson, f. and Niemcrynowicz, 1. 1994. Multufractal relations in rainfall data. In Spatial and temporal variability and interdependencies among hydrological processes. Edited by I. Kettunen, K. Granlund, M. PaasonenKivekäs and H. Sinviö. Proc. of Nordic Seminar, September 14-16, 1994, Kirkkonummi, Finland. NHP Report No. 36, pp. 110.119.

Palmer.W.C. 1965. Meteorological drought. U.S. Department of Commerce. Weather Bureau research paper. Washington, D.C.. $N^{\circ} 45$.

Pimenta, R.E. 1998. Combate à desertificação em Portugal Continental - Utilizaçăo de SIG na caracterizaçāo de secas. M.Sc. thesis, Departamento de Engenharia Civil da Faculdade de Ciências e Tecnologia da Unversidade de Coimbra, Coimbra, Portugal.

Pimenta. M.R E. and Lima, J. L. M. P. de 1999. Utilização do Método de Palmer e de SIG para a caracterização de secas em Portugal Continental. Actas do IV Simpósio de Hidráulica e Recursos Hidricos dos Paises de Lingua Oficial Portuguesa (IV SILUSBA), APRHIABPH/AMCT, May 24-26, 1999. Coimbra, Portugal. $8 p$.

Schertzer. D. and Lovejoy. S. 1983. Elliptical turbulence in the atmosphere. Proc. of Fourth Symposium on Turbulent Shear Flows, Karlshule. West Germany, pp. 11.1-11.8.

Schertzer. D. and Lovejoy, S. 1987. Physical modeling and analysis of rain and clouds by anisotropic scaling multiplicative processes.1. Geophys Res. 92(D8): 9693-9714.

Schertzer. D. and Lovejoy. S. 1989. Nonlinear variability in Geophysics multifractal simulations and analysis. In Fractals' physical origin and properties. Edrted by L Pietronero. Plenum Press. New York. pp. 49-79.

Sevruk, B., and Klemm. S. 1989. Types of standard precipitation gauges. In Precipitation measurements. Edited by B. Sevruk. Proceedings of WMO/AHS/ETH Internatoonal Workshop on Precipitation Measurements. December 3-7. 1989, St. Moritz. Switzerland. pp. 227-232

Svensson, C., Oisson, J., and Berndtsson, R 1996 Mulufractal properties of daily rainfall in two different climates. Water Resour. Res, 32(8): 2463-2472.

Tessier, Y, Lovejoy, S, and Schertzer, D. 1992 Universal mutufractals: theory and observations for rain and clouds. Proc of I I th International Conference on Clouds and Precipitation. Montreal, Canada. Vol. 2.pp. 1098-1101.

Tessier, Y, Lovejoy, S., and Schertzer, D. 1993. Universal multifractals; theory and observations for rain and clouds.f. Appl. Meteorol. 32(2): 223-250.

Tessier, Y, Lovejoy, S., Hubert, P, Schertzer, D., and Pecknold, S. 1996. Multufractal analysis and modeling of rainfall and river flows and scaling, causal transfer functions. I. Geophys Res, 101(D21): 26427-26440. 

Série

Investigação

$\bullet$

Coimbra

Imprensa da Universidade

2002 